\title{
Dispersal by cattle of salt-marsh and dune species into salt-marsh and dune communities
}

\author{
J. P. Bakker · L. Gálvez Bravo · A. M. Mouissie
}

Received: 14 November 2006/ Accepted: 14 September 2007/Published online: 12 October 2007

(C) Springer Science+Business Media B.V. 2007

\begin{abstract}
Seed dispersal via ingestion and defecation by large herbivores (endozoochory) plays a potentially important role in structuring plant communities. In the present study we tested whether cattle disperse seeds between different plant communities in a heterogeneous coastal habitat. We surveyed the seed contents of cattle dung collected from two habitat types within a grazing system, one in dunes and the other in saltmarsh. The dunes are characterized by sandy soil, and infrequent inundation by the sea, whereas the salt-marsh features clay deposited during inundations. Seeds of both salt-marsh and dune species were dispersed into salt-marsh and dune habitats. The seed content of cattle dung collected in salt-marsh and dunes was similar with respect to species composition and seed density. However, dispersal of dune species into salt-marsh and vice-versa did not result in establishment in those communities. Seed traits
\end{abstract}

J. P. Bakker $(\bowtie)$ · A. M. Mouissie

Community and Conservation Ecology Group, University of Groningen, 14, Haren 9750 AA, The Netherlands e-mail: J.P.Bakker@rug.nl

L. Gálvez Bravo

Departamento de Ecología, Universidad de Alcalá.

Edif. de Ciencias, Campus Universitario.

Ctra. Madrid-Barcelona, Km. 33600. 28871,

Alcalá de Henares, Madrid, Spain

A. M. Mouissie

Grontmij Netherlands, 119, Houten 3990 DC,

The Netherlands per se did not differ between dune species and saltmarsh species. Species abundance in the established vegetation and seed density in dung were positively correlated. Seed abundance for most species found in dung was consistent with the availability of viable seeds during the growing season. Seed mass, seed 'roundness' and seed release height were all negatively correlated with seed numbers in dung. An indirect factor, namely, forage quality of the plant, and hence attractiveness for herbivores, could explain the higher likelihood of seed dispersal of salt-marsh species than of dune species. The salt-marsh harbours species with higher forage quality than the dune species, as derived from Ellenberg nitrogen indicator values.

Keywords Endozoochory - Forage quality · Indicator values $\cdot$ Seed mass $\cdot$ Seed shape

\section{Introduction}

Seeds of many plant species are capable of surviving the digestive tract (Cosyns and Hoffmann 2005; Mouissie et al. 2005a) and are found in dung samples (e.g. Welch 1985; Malo and Suarez 1995a; Dai 2000; Bruun and Poschlod 2006). Hence, large herbivores play an important role in dispersal of plants

After ingestion, seeds usually remain in the digestive tract of large herbivores for several days before defecation (Cosyns and Hoffmann 2005; Mouissie et al. 2005a). Hence, ingested seeds can 
potentially be dispersed over a long distance (Pakeman 2001; Vellend et al. 2003). Thus ingested seeds may be deposited into habitat types in which the species grows or into another habitat type (Mitlacher et al. 2002).

Little studies reveal the relationship between the established vegetation, its seed production, seeds characteristics and dispersal of seeds by herbivores in a heterogeneous landscape. We asked to which extent the seed supply via cattle dispersal is an important factor in the composition of dune and saltmarsh plant communities. The first question we addressed is the composition of seed dispersal into the two habitats. The second question is to which extent seed dispersal depends on characteristics of the plant communities in relation to the herbivores. We hypothesised that three factors could be important for seed dispersal by large herbivores, namely, (1) seeds per se, particularly, seed size, seed shape, and seed longevity, (2) seed availability (abundance of species in the vegetation, phenology, i.e. seed presence during the growing season), or (3) nonseed related factors, especially, forage quality of foliage, and hence the interaction of plants and herbivores.

\section{Material and methods}

Study area

The study was carried out on the coastal barrier island of Schiermonnikoog, The Netherlands $\left(53^{\circ} 30^{\prime} \mathrm{N}\right.$, $\left.6^{\circ} 10^{\prime} \mathrm{E}\right)$. The island features dunes along the North Sea coast and salt-marshes along the Wadden Sea coast. Until 1958 the entire salt-marsh and adjacent dunes were grazed by cattle tended by a herdsman. Because of veterinary reasons, only the most western part (50 ha) of the salt-marsh and dunes were grazed by cattle since 1958. From 1972 onwards the fenced area was gradually extended up to the current 415 ha. However, about $40 \%$ of the area is virtually ungrazed. It includes high dunes covered by Hippophae rhamnoides shrubs and tall Calamagrostis epigejos grass. Plant nomenclature including authorities of scientific names follows Van Der Meijden (1990). The wet valleys in between are covered by Betula pubescens trees and tall Phragmites australis and Scirpus maritimus reeds. The remainder is grazed by about 220 heifers from early May until late October. The present study focuses on the relatively heavily grazed salt-marsh (100 ha) with the grasses Festuca rubra, Agrostis stolonifera, Elymus athericus, the rushes Juncus gerardi, J. maritimus, and the herbs Armeria maritima, Potentilla anserina, Plantago maritima, Trifolium repens, and the low dunes (150 ha) covered by the grasses Ammophila arenaria, Poa pratensis, Agrostis capillaris, Holcus lanatus, and the herbs Stellaria graminea, Plantago lanceolata (see further Appendix 1). The number of cattle dung patches is c. 15/ha/day in the salt-marsh, and c. $10 /$ ha/day in the dune area (Bakker 1989). The vegetation of the low dunes and the salt-marsh was characterized by relevés in the 1980s. The low dunes are between 165 and $205 \mathrm{~cm}$ above Dutch Ordnance Level, and can be inundated up to two times a year. The salt-marsh ranges between 40 and $120 \mathrm{~cm}$ above Dutch Ordnance Level, and features an annual inundation frequency between 7 and 80 (Bakker 1989).

\section{Established vegetation}

The relative abundance of the different plant species present in the established vegetation of the heavily grazed part of the study area was recorded according to the Tansley scale ranging from rare, occasional, frequent, abundant to dominant (Tansley 1946). We walked transects across the low dunes and salt-marsh habitat. Species were classified as 'dune species' or 'salt-marsh species' according to Van Der Meijden (1990). The aforementioned relevés indicate that no salt-marsh species occur in the dune area and viceversa (Bakker 1989). The nitrogen numbers as indicators of nutrient availability, and hence forage quality for species, follow Ellenberg et al. (1991).

Additionally, data on presence of seeds at different periods of the year and seed release height of the plants were obtained by field visits during the growing season.

Viable seeds in dung in the salt-marsh and dunes

The dispersal of seeds through the faeces of cattle was evaluated by collecting dung at two habitat types. One site was situated at the salt-marsh, the other at 
the dunes. The sites were at a distance of $1000 \mathrm{~m}$ from each other. Cattle had equal access to both sites within the fence. A total of 801 samples of fresh cattle dung were collected. The samples were collected from large dung pats, thus avoiding contamination by propagules from the soil. Twenty samples were collected, 10 at each site separated at least $10 \mathrm{~m}$ from each other, on the 18th of June, 14th of July, 3rd of September and 18th of October 2000. The fresh samples were stored during 4 weeks at $4{ }^{\circ} \mathrm{C}$ in order to stratify the seeds present in the dung.

The seed contents of samples were quantified using a modified seedling emergence technique (Ter Heerdt et al. 1996). The seeds were concentrated by forcing the samples through a series of sieves $(2,0.212 \mathrm{~mm})$ using a strong jet of water. The remaining faecal material and seed concentrate were transferred to a greenhouse $\left(25^{\circ} \mathrm{C}\right.$ day temperature, $15^{\circ} \mathrm{C}$ night temperature, $15 \mathrm{~h}$ light period, automatic watering for 1 min twice a day). The samples were spread in a thin layer $(<5 \mathrm{~mm})$ in containers filled with sterile potting soil and a fine layer (around $4 \mathrm{~mm}$ ) of sterile sand. Emerging seedlings were counted and removed as soon as identification was possible. Where identification was difficult, seedlings were transplanted to separate containers and allowed to mature. Germination had usually ceased after 6 weeks and samples were then left to dry for a week. The dried samples were then crumbled, watered and monitored at least two additional weeks for seedling emergence. This last procedure was applied in order to expose seeds buried in the deeper layers of the samples to light, thereby decreasing the chance that seeds remained dormant (Ter Heerdt et al. 1996; Wolters et al. 2004).

\section{Seed traits}

Information about seed mass, length, width and breadth was obtained from the database BIOFLOR (Klotz et al. 2002). Using the values for seed length, width and thickness, the variance in seed dimensions was calculated, producing a seed shape index $\left(V_{\mathrm{s}}\right)$, which is indicative of seed roundness (Bekker et al. 1998). Information on seed longevity was obtained from Thompson et al. (1997), and a seed longevity index was calculated according to Bekker et al. (1998).
Data analysis

In order to show that there were no significant differences in seed density or number of species found in dung from the two habitat types salt-marsh and dune, a Mann Whitney test was carried out. Both seed density $(P=0.946)$ and species richness $(P=0.396)$ did not differ significantly between the two sampling sites. Hence subsequent analyses were all conducted on the pooled data set for both sites, sample $n=20$ per collection date.

A simple Pearson's correlation was performed to test whether the species composition of the seeds found in dung reflected the established vegetation. In this case, seed density data were $\log _{10}$-transformed to achieve homogeneity of variances.

For the purposes of data analysis, the Tansley scale according to which the established vegetation was quantified, was converted to numbers $(0=$ not present in the vegetation, but found in dung samples, $1=$ rare, 2 = occasional, 3 = frequent, $4=$ abundant; species dominant in the entire study area did not occur).

In order to investigate possible temporal patterns in seed dispersal, a non-parametric analysis of variance was conducted (Kruskal-Wallis) with species richness and seed density data of the four sampling periods, both for salt-marsh and dune species. If significant differences were found, these were tested using Dunnett's T3 test due to nonhomogeneity of variances. To assess significant temporal patterns of individual species, repeated measures analyses were performed (see Boedeltje et al. 2004). A total of 25 species were included, those which had $>10$ records in at least two of the sampling periods. The analyses produced ANOVA tables of which only the 'within-subject time effect table was used. The conservative Greenhouse-Geisser $P$-value was used to explore the significance of the results due to the data not being spherical. For both types of analyses $\log _{10}$-transformed data were used.

Due to the non-parametric nature of data, Spearman's rank correlation was used to explore the relationships between seed densities in dung and species abundance in the established vegetation, seed release height data and different seed traits, seed mass $(\mathrm{mg})$, seed roundness (expressed as variance in seed dimensions $V_{\mathrm{s}}$ see Pakeman et al. 2002) and seed 
longevity. When the relationship was non-significant, a partial correlation was performed using abundance of species in the established vegetation as control factor. Spearman's rank correlations were also performed with data about the usually preferred habitat for each species: salt-marsh or dune. A Mann-Whitney test was carried out testing the differences in mean Ellenberg nitrogen indicator values (Ellenberg et al. 1991), seed traits and seed release height between salt-marsh and dune species. Ellenberg nitrogen numbers are indicators of the nutrient availability in soils where plant species most frequently grow. The scale runs from 1 to 9 , with Ellenberg number 9 indicating species growing on the most nutrient-rich soils and 1 indicating species growing on the poorest soils.

All analyses were carried out using SPSS 11.0 for Windows (SPSS, Inc. 2001).

\section{Results}

Seasonal seed contents of dung

A total of 24,534 seedlings were found in dung (an average of 306.7 seeds/l). The number of seeds did not differ between June, July and September, but was significantly lower in October than in previous months. Salt-marsh species abundance in dung was highest in June $(P<0.0001)$, whilst seeds of dune species were most abundant in July $(P=0.018)$ (Fig. 1). The most abundant species in dung were the salt-marsh species Sagina procumbens, Agrostis stolonifera, Trifolium repens, Juncus gerardi, Poa апnиa, and the dune species Poa pratensis. Graminoids were the most abundant family in dung (27\%), Asteraceae and Caryophyllaceae were also quite abundant ( 9 and $10 \%$, respectively) (Appendix 1).

A total of 60 species were found in dung (an average of 13.3 species/l). The number of species was significantly lower in June than later in the season with highest numbers in September. Saltmarsh species richness was significantly higher in September $(P<0.0001)$. The number of dune species was very low in June and remained similar throughout the rest of the year $(P<0.0001)$ (Fig. 2). The 60 species found represent $58 \%$ of the total number of species present in the established

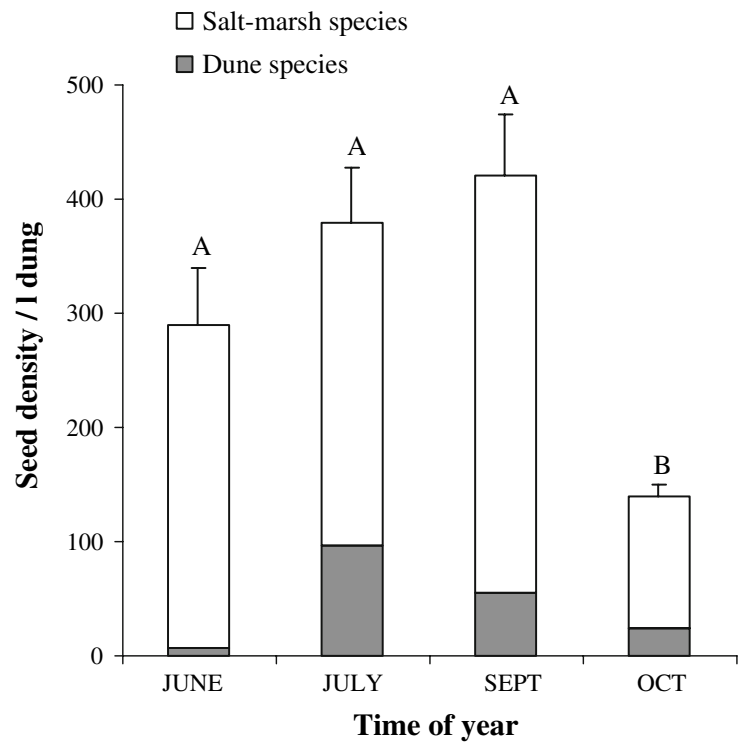

Fig. 1 Viable dune and salt-marsh seed density (seeds/l dung) in cattle dung throughout the year. Different letters above the bars indicate significant differences $(P \leq 0.001)$ following the post hoc Dunnet's T3 test. Error bars represent standard error of the mean

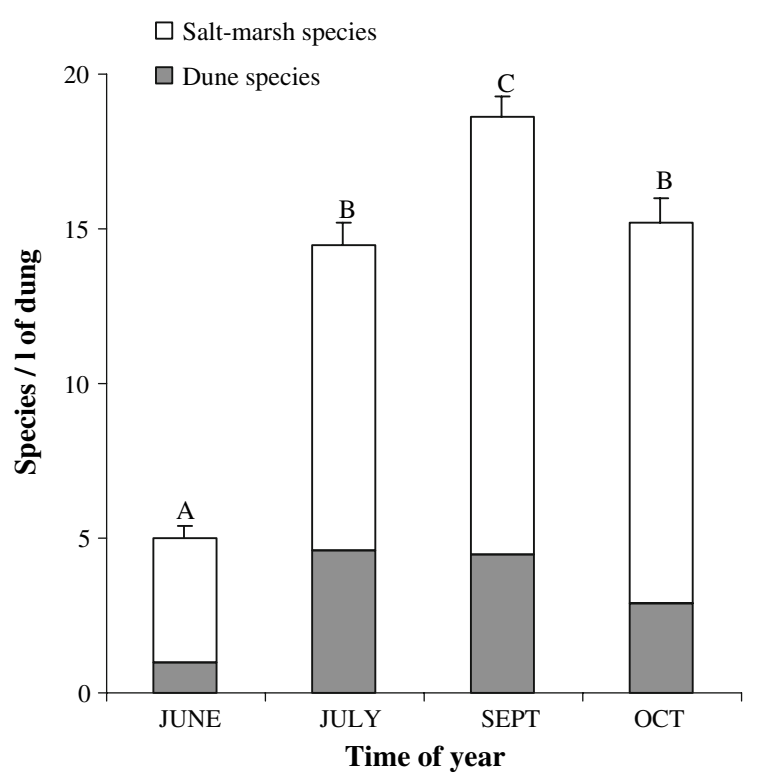

Fig. 2 Number of dune and salt-marsh species per litre of cattle dung throughout the year. Different letters above the bars indicate significant differences $(P<0.001)$ following the post hoc Dunnet's T3 test. Significantly less species were dispersed in this way in June $(P<0.001)$. The greatest number of species are dispersed in September $(P<0.001)$, whilst July and October samples contained the same number of species. Error bars represent standard error of the mean 


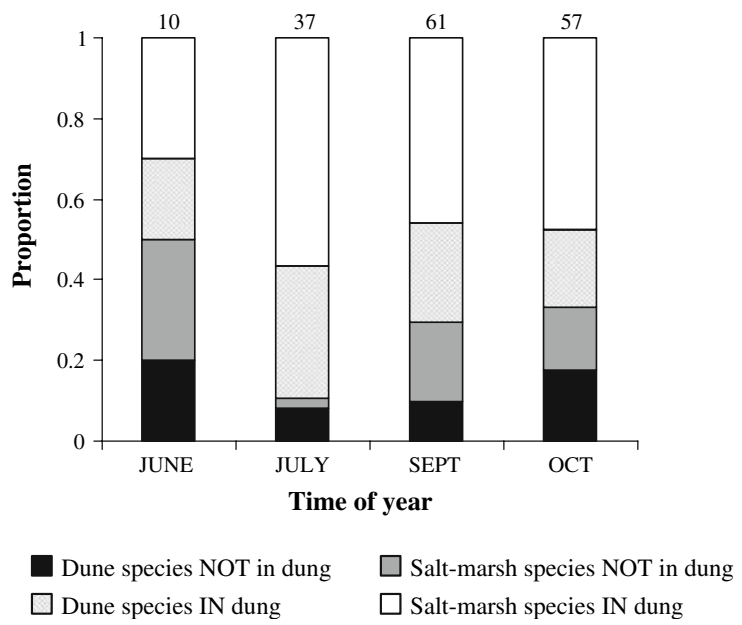

Fig. 3 Proportions of total dune and salt-marsh species with viable seeds that were present or not present in dung at the different sampling periods. Numbers above bars represent total number of species with available seeds

vegetation of the heavily grazed area. July dung samples contained the highest proportion $(89 \%)$ of species with available seeds at that time, for both saltmarsh and dune species. Fifty-seven percent of available salt-marsh species were dispersed in July and $32 \%$ of available dune species (Fig. 3).

Results from the repeated measures analyses show that most species with $>10$ records in dung in at least two of the sampling periods have marked seasonal dispersal patterns (Table 1). The presence of seeds of each species in cattle dung is obviously conditioned by the availability of seeds in the vegetation. However, the seasonal pattern is not the same for all species. Species at the top of Table 1 are dispersed mainly in June and July, whereas those at the bottom of the table have their peaks of dispersal later in the year. Most species that just flower in June are not found as viable seeds in dung in the same month. However, some exceptions such as Plantago coronopus, Juncus maritimus, Poa pratensis and Juncus gerardi are found in dung in June, before they have set fresh seeds.

Throughout the year, dung contained approximately $70 \%$ of salt-marsh and $30 \%$ of dune seeds, irrespective of where dung had been collected, and not taking into account presence of seeds in the vegetation. When presence of seeds is taken into account $64 \%$ of salt-marsh species and $48 \%$ of dune species were found in dung throughout the year.
Species composition of seeds in dung at the salt-marsh and at the dunes

No significant differences were found in species composition or seed density between dung samples collected the salt-marsh site and at the dune site, as mentioned in the data analysis section. Seed density in dung was significantly higher $(P=0.03)$ for saltmarsh species than for dune species (Table 2).

The established vegetation in the heavily grazed part of the study area harboured 55 salt-marsh species and 48 dune species (Appendix 1). Of the salt-marsh species, $35(64 \%)$ were also found in the dung with one or more viable seeds. Twenty species were not found in the dung of which Artemisia maritima, Aster tripolium, Limonium vulgare, Phragmites australis, Scirpus maritimus occurred occasionally or frequently in the established vegetation. Of the dune species 23 (48\%) were also found in the dung. Twenty-five species were not found in the dung, but Ammophila arenaria, Carex arenaria, Danthonia decumbens, Hypochaeris radicata, Leontodon saxatile, Trifolium arvense, Tripleurospermum maritimum occurred occasionally or frequently in the established vegetation. A significantly higher $(P=0.026)$ proportion (64\%) of salt-marsh species were found in cattle dung as opposed to sand dune species (48\%). Also, more species which are frequently found in sand-dune vegetation were then not found in dung, and this happened with fewer salt-marsh species.

Seed density in the dung and species abundance in the established vegetation were significantly positively correlated at $P<0.0001$ ( $r=0.491)$ (Fig. 4).

Relationships with seed traits, abundance and forage quality

Seed mass, seed 'roundness' $\left(V_{\mathrm{s}}\right)$ and seed release height were not significantly different for salt-marsh and dune species $(P=0.138,0.939$, and 0.083 , respectively) (Table 2). Seed mass, seed 'roundness' and seed release height were all significantly negatively correlated with seed numbers in dung only after performing a partial correlation and correcting for abundance of each species in the vegetation (Table 3). A significantly positive correlation was found between seeds in dung with seed longevity, but 
Table 1 Species and number of seeds at the different sampling periods and ANOVA results from repeated measures analyses of species with $\geq 10$ records in at least two sampling periods

\begin{tabular}{|c|c|c|c|c|c|c|c|c|c|c|c|}
\hline & June & $\begin{array}{l}\text { Seeds } \\
\text { present }\end{array}$ & July & $\begin{array}{l}\text { Seeds } \\
\text { present }\end{array}$ & Sep & $\begin{array}{l}\text { Seeds } \\
\text { present }\end{array}$ & Oct & $\begin{array}{l}\text { Seeds } \\
\text { present }\end{array}$ & Df & $F$ & $P$-value \\
\hline Sagina procumbens $(\mathrm{S})$ & 4697 & + & 4540 & + & 308 & + & 74 & + & 3 & 84.35 & 0.000 \\
\hline Poа аппиа (S) & 915 & + & 106 & + & 31 & + & 26 & + & 3 & 29.28 & 0.000 \\
\hline Cerastium fontanum (D) & 56 & + & 515 & + & 24 & + & 2 & + & 3 & 9.060 & 0.000 \\
\hline Plantago coronopus (D) & 47 & $(+)$ & 513 & + & 210 & + & 133 & + & 3 & 8.814 & 0.000 \\
\hline Juncus maritimus (S) & 21 & $(+)$ & 22 & + & 3 & + & 225 & + & 3 & 16.74 & 0.000 \\
\hline Poa pratensis (D) & 12 & $(+)$ & 759 & + & 547 & + & 164 & + & 3 & 98.24 & 0.000 \\
\hline Juncus gerardi (S) & 8 & $(+)$ & 19 & + & 692 & + & 533 & + & 3 & 98.90 & 0.000 \\
\hline Juncus ambiguous (S) & 1 & $(+)$ & 106 & + & 80 & + & 18 & + & 3 & 2.867 & 0.000 \\
\hline Plantago lanceolata & 1 & $(+)$ & 86 & + & 44 & + & 26 & + & 3 & 6.363 & 0.004 \\
\hline Potentilla anserina $(\mathrm{S})$ & 1 & $(+)$ & 31 & + & 15 & + & 87 & + & 3 & 7.634 & 0.001 \\
\hline Juncus articulatus (S) & 1 & $(+)$ & 17 & + & 28 & + & 76 & + & 3 & 5.705 & 0.069 \\
\hline Rumex acetosella (D) & 1 & $(+)$ & 17 & + & 5 & + & 14 & + & 3 & 2.917 & 0.061 \\
\hline Stellaria media (D) & 1 & $\times$ & 11 & $\mathrm{x}$ & 28 & $x$ & 0 & $x$ & 3 & 4.999 & 0.019 \\
\hline Plantago major (D) & 1 & - & 0 & - & 13 & + & 115 & + & 3 & 6.102 & 0.015 \\
\hline Spergularia maritima $(\mathrm{S})$ & 0 & $(+)$ & 324 & + & 440 & + & 87 & + & 3 & 76.38 & 0.000 \\
\hline Festuca rubra $(\mathrm{S})$ & 0 & $(+)$ & 269 & + & 105 & + & 5 & + & 3 & 41.33 & 0.000 \\
\hline Sagina nodosa $(\mathrm{S})$ & 0 & $(+)$ & 36 & + & 78 & + & 2 & + & 3 & 11.12 & 0.000 \\
\hline Carex distans $(\mathrm{S})$ & 0 & $(+)$ & 35 & + & 28 & + & 153 & + & 3 & 9.578 & 0.002 \\
\hline Trifolium repens $(\mathrm{S})$ & 0 & $(+)$ & 33 & + & 1403 & + & 229 & + & 3 & 124.3 & 0.000 \\
\hline Poa trivialis $(\mathrm{S})$ & 0 & $(+)$ & 31 & + & 15 & + & 0 & - & 3 & 2.127 & 0.133 \\
\hline Lolium perenne $(\mathrm{S})$ & 0 & $(+)$ & 2 & + & 126 & + & 24 & + & 3 & 17.37 & 0.000 \\
\hline Suaeda maritima $(\mathrm{S})$ & 0 & - & 0 & - & 172 & + & 13 & + & 3 & 20.84 & 0.011 \\
\hline Glaux maritima $(\mathrm{S})$ & 0 & $(+)$ & 0 & $(+)$ & 133 & + & 42 & + & 3 & 41.39 & 0.004 \\
\hline Plantago maritima $(\mathrm{S})$ & 0 & - & 0 & - & 130 & + & 71 & + & 3 & 13.95 & 0.000 \\
\hline Centaurium pulchellum (S) & 0 & - & 0 & - & 26 & + & 32 & + & 3 & 7.686 & 0.000 \\
\hline
\end{tabular}

Species at the top of the table are mostly dispersed in summer, whereas those at the bottom are mainly dispersed in autumn Key: $-=$ seeds not present, $(+)=$ flowers present but no seeds, $+=$ seeds present, $\times=$ no data available, $(D)=$ dune species, (S) = salt-marsh species

Statistics: Significant $P$-values shown in bold

Table 2 Comparison (Mann-Whitney $U$-test) between dune and salt-marsh plant species for seed traits and Ellenberg nitrogen indicators

\begin{tabular}{llllc}
\hline Traits & $\begin{array}{l}\text { Mean for } \\
\text { dune species }\end{array}$ & $\begin{array}{l}\text { Mean for salt- } \\
\text { marsh species }\end{array}$ & $\begin{array}{l}\text { Mann- } \\
\text { Whitney } U\end{array}$ \\
\hline Seed mass $(\mathrm{mg})$ & $1.43 \pm 0.45$ & $0.55 \pm 0.09$ & 514 & 0.14 \\
Seed dimensions $\left(V_{\mathrm{s}}\right)$ & $0.12 \pm 0.01$ & $0.12 \pm 0.01$ & 734 & 0.94 \\
Seed release height $(\mathrm{cm})$ & $19.4 \pm 2.52$ & $14.9 \pm 2.11$ & 798 & 0.08 \\
Seed longevity index & $0.38 \pm 0.46$ & $0.52 \pm 0.06$ & 533 & 0.15 \\
Ellenberg N number & $4.07 \pm 0.31$ & $5.20 \pm 0.28$ & 700 & $\mathbf{0 . 0 0 8}$ \\
Seed density (seeds/l) & $0.95 \pm 0.47$ & $4.75 \pm 2.37$ & 998 & $\mathbf{0 . 0 3}$ \\
\hline
\end{tabular}

Significant results are indicated in bold 


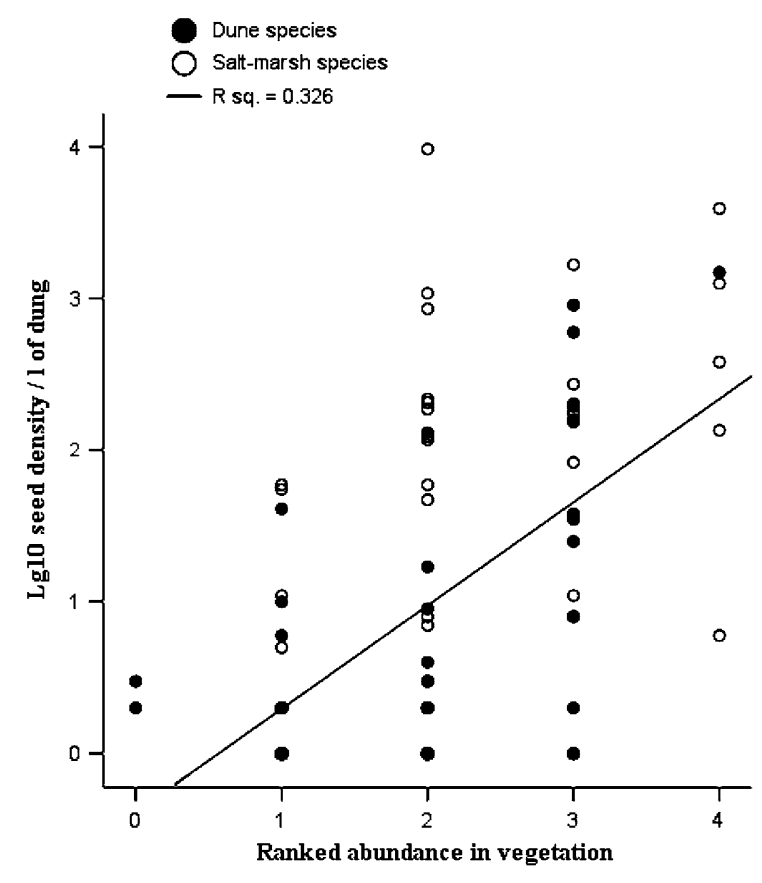

Fig. 4 Results of Pearson correlation between the number of seeds of dune and salt-marsh species found in dung and abundance ranks in the vegetation. The graph shows a significant positive relationship $\left(R^{2}=0.33, P<0.001\right)$ which means that seeds found in cattle dung represent the most abundant species in the established vegetation, and this holds for both dune $\left(R^{2}=0.37, P<0.001\right)$ and salt-marsh species $\left(R^{2}=0.33, P<0.001\right)$

Table 3 Spearman's Rho correlations of seeds in dung with plant traits and $P$-values

\begin{tabular}{|c|c|c|}
\hline Correlation & Coefficient $(r)$ & $P$-value \\
\hline Seed mass vs. seed density & -0.18 & 0.12 \\
\hline $\begin{array}{l}\text { Seed mass vs. seed density } \\
\text { with abundance as control }\end{array}$ & -0.29 & 0.02 \\
\hline $\begin{array}{l}\text { Seed dimensions }\left(V_{\mathrm{s}}\right) \text { vs. seed } \\
\text { density }\end{array}$ & -0.19 & 0.1 \\
\hline $\begin{array}{l}\text { Seed dimensions }\left(V_{\mathrm{s}}\right) \text { vs. seed } \\
\text { density with abundance as } \\
\text { control }\end{array}$ & -0.24 & 0.04 \\
\hline Seed longevity vs. seed density & +0.16 & 0.17 \\
\hline $\begin{array}{l}\text { Seed longevity vs. seed density } \\
\text { with abundance as control }\end{array}$ & +0.28 & 0.02 \\
\hline Seed release height & -0.17 & 0.12 \\
\hline $\begin{array}{l}\text { Seed release height vs. seed } \\
\text { density with abundance as } \\
\text { control }\end{array}$ & -0.32 & 0.002 \\
\hline
\end{tabular}

Significant correlations are indicated in bold also only when controlling for abundance in the vegetation (Table 3 ).

No differences were observed in seed mass or seed dimensions between species found or not found in dung (mass: mean for species present in dung $=0.89 \pm 0.22 ;$ mean for species not in dung $=1.30 \pm 0.64, P=0.995$; dimensions: mean for species present in dung $=0.11 \pm 0.009$; mean for species not in dung $=0.13 \pm 0.013, \quad P=0.172$; longevity: mean for species present in dung $=0.46$ \pm 0.045 ; mean for species not in dung $=0.40$ $\pm 0.077, P=0.354$ ).

Salt-marsh species had significantly higher Ellenberg nitrogen indicator values $(P=0.008)$ than dune species (means: 5.20 and 4.07, respectively) (Table 2).

\section{Discussion}

Seed dispersal of salt-marsh and dune species

We found a positive relationship between abundance in the vegetation and seed density in dung (Fig. 4). The seasonality of numbers of seeds found in dung suggests dependence on the availability of seeds in the established vegetation (Table 1). Bruun and Poschlod (2006) also found that the numbers of seeds in cattle dung were proportional to seed production at the grazed site.

Dung collected in both habitat types contained both salt-marsh species and dune species. The composition of cattle dung pats collected in saltmarsh or dune parts of the study area did not differ significantly. Cattle dung contained high numbers of viable seeds, namely 307 seeds/l fresh weight of 60 species, indicating that cattle are an important vector for seed dispersal.

We did not find other studies that compared seed contents in dung collected in different habitats. Yet, the species composition in dung of herbivores found in other studies suggests that the dispersal of seeds between different habitats is a more common phenomenon than expected. Dung collected in a grassland-woodland mosaic in the Netherlands contained seeds of all habitat types (Bakker and Olff 2003). This was also the case in a heathlandgrassland-woodland area (Mouissie et al. 2005b) and in a heterogeneous coastal habitat in Belgium 
(Cosyns and Hoffmann 2005) and Mediterranean dehesa (Malo and Suarez 1995b). Welch (1985) recovered seeds of grassland species in dung collected in heathland in Scotland. The proportion of species found in herbivore dung compared to the species in the established vegetation ranges from 21 to $72 \%$ in the above studies.

Factors determining seed dispersal of salt-marsh and dune species

We found no differences in seed traits between seeds present or not present in dung. These results are similar to Cosyns and Hoffmann's (2005) study on horse dung. They suggested that once small, round seeds have been selected to survive through the molar mills and gut, seed shape is of no further relevance for survival, dispersal and finally establishment in the vegetation.

Significant negative correlations with seed traits showed that smaller, rounder seeds are more likely to be found in dung, and also seeds of plant species which present fruiting bodies closer to the ground (Table 3). Seed survival after ingestion by Fallow deer is negatively related to seed mass and variance in seed 'roundness' and positively related to seed persistence (seed longevity index). Most variation in seed survival can be explained by seed mass (Mouissie et al. 2005c). More resistant seeds (with a higher longevity index) also have a greater chance to survive gut passage and appear in the dung. Small and round seeds may have a higher chance to escape from chewing molars than big and flat or elongated seeds, as was also found by Pakeman et al. (2002). Simao Neto et al. (1987), Gardener et al. (1993), Pakeman et al. (2002) and Mouissie et al. (2005b) observed that plant species recorded in dung have lower seed mass than species that were not found in dung, as we found in the present study. However, these authors did not report that species detected in dung were rounder (had lower variance in unit seed dimensions) than species not found in dung. Still, a negative relationship between seed mass and seed numbers in dung is not always found, as demonstrated by Bruun and Poschlod (2006).

Seed mass and shape do not differ between saltmarsh and dune species. Hence, it is unlikely that saltmarsh species have a higher chance to survive the alimentary tract. It is more likely that cattle prefer saltmarsh species. This may be related to the significantly higher Ellenberg nitrogen indicator value of saltmarsh species than dune species. This is in agreement with the positive correlation between Ellenberg nitrogen indicator values and the numbers of viable seeds in dung related to the seed supply for cattle, pony and sheep found by Mouissie et al. (2005b). A high proportion of nitrophilous species in dung samples was also reported by Welch (1985) and Malo and Suarez (1995a). An explanation might be the higher palatability of plants on fertile soils as compared to unfertile soils according to the carbon/nitrogen balance hypothesis (Bryant et al. 1983). The species that are not found in dung could be avoided by cattle because of their low palatability such as Artemisia maritima at the salt-marsh or Ammophila arenaria at the dunes. In contrast, highly palatable species such as Aster tripolium may be at a disadvantage because they are actively selected by cattle before they have a chance to flower and set seed, hence they were not found in dung. The same holds for Puccinellia maritima of which only a few viable seeds were found in dung. This idea is supported by reports on different grazing intensities in dry grassland. At low grazing intensity a reduction of the infructescences of abundant species of about $25 \%$ was found, whereas at more intensive grazing this was of about $70 \%$ (Kratochwil et al. 2002). Vellend et al. (2006) refer to this phenomenon as the antagonistic effects of seed dispersal and herbivory on plant migration.

Viable seeds of salt-marsh species were more likely to be found in dung than those of dune species, whereas salt-marsh and dune species do not differ in the chance to disintegrate in the alimentary tract (Table 2). This is despite the fact that cattle can forage on a larger dune area than salt-marsh area. Cattle have different preferences for grazing and resting. They prefer to rest and ruminate in the dry dune habitat (Bakker 1989), and prefer to graze in the salt-marsh habitat where they find more species with good forage quality (present study) Consequently more seeds of salt-marsh than dune species could be dispersed.

Endozoochory and community structure

We do not know whether seedlings on dung pats survived, emerged and eventually established in the vegetation of the study area. It is difficult to verify whether salt-marsh species dispersed through dung do 
establish into an existing salt-marsh community, and dune species into an existing dune community. However, in our study area the salt-marsh community does not harbour dune species, and the dune community does not harbour salt-marsh species (Bakker 1989). Although cattle disperse seeds homogeneously over a heterogeneous habitat, the latter does not homogenize due to a strong filter. Such a filter could be abiotic such as different soil, elevation and hence inundation frequency or biotic such as competition of the established vegetation. A next step would be to study at which phase (germination, seedling, early establishment) such a filter acts. Apparently, spill-over of species takes place when individuals disperse into a non-habitat in heterogeneous sites. Endozoochorous dispersal of salt-marsh and dune species into their 'own' habitat, may play a role next to other dispersal vectors such as wind and inundation water to maintain these communities.

\section{Appendix 1}

Species and seed trait data for seeds found in cattle dung, Ellenberg nitrogen-indicator values, abundance categories, presence of seeds and seed release height for each species

\begin{tabular}{|c|c|c|c|c|c|c|c|c|}
\hline \multirow[t]{2}{*}{ Species } & \multirow{2}{*}{$\begin{array}{l}\text { Ellenberg } \\
\text { Nitrogen } \\
\text { numbers }\end{array}$} & \multirow{2}{*}{$\begin{array}{l}\text { Occur. } \\
\text { in veg. }\end{array}$} & \multirow{2}{*}{$\begin{array}{l}\text { Seeds in } \\
\text { dung (80 1) }\end{array}$} & \multirow{2}{*}{$\begin{array}{l}\text { Months with } \\
\text { seeds present } \\
\text { in vegetation }\end{array}$} & \multicolumn{4}{|l|}{ Seed traits } \\
\hline & & & & & $\begin{array}{l}\text { Seed release } \\
\text { height }(\mathrm{cm})\end{array}$ & $\begin{array}{l}\text { Seed } \\
\text { mass } \\
(\mathrm{mg})\end{array}$ & $\begin{array}{l}\text { Seed } \\
\operatorname{dim} . \\
\left(V_{\mathrm{s}}\right)\end{array}$ & $\begin{array}{l}\text { Seed } \\
\text { longevity } \\
\text { index }\end{array}$ \\
\hline Achillea millefolium (D) & 5 & o & 0 & Jl.A.S.O & 20 & 0.13 & 0.18 & 0.09 \\
\hline Agrostis canina (D) & 2 & - & 1 & - & 10 & 0.05 & 0.20 & 0.5 \\
\hline Agrostis capillaris (D) & 4 & $\mathrm{f}$ & 193 & A.S.O & 15 & 0.06 & 0.16 & 0.69 \\
\hline Agrostis stolonifera $(\mathrm{S})$ & 5 & a & 3904 & Jl.A.S.O & 10 & 0.02 & 0.15 & 0.42 \\
\hline Alopecurus geniculatus (S) & 7 & $\mathrm{r}$ & 4 & J.Jl.S & 10 & 0.37 & 0.09 & 0.6 \\
\hline Ammophila arenaria (D) & 5 & $\mathrm{f}$ & 0 & A.S.O & 50 & - & - & 0.09 \\
\hline Anthoxanthum odoratum(D) & - & o & 1 & - & 50 & 0.52 & 0.17 & 0.28 \\
\hline Armeria maritima $(\mathrm{S})$ & 4 & a & 5 & J1.A.S.O & 10 & 0.88 & 0.10 & 0 \\
\hline Artemisia maritima $(\mathrm{S})$ & 2 & $\mathrm{f}$ & 0 & S.O & 50 & - & - & - \\
\hline Aster tripolium $(\mathrm{S})$ & 7 & o & 0 & S.O & - & - & 0.21 & 0.75 \\
\hline Atriplex litoralis $(\mathrm{S})$ & 9 & $\mathrm{r}$ & 1 & S.O & - & 1.21 & 0.14 & - \\
\hline Atriplex portulacoides $(\mathrm{S})$ & 7 & $\mathrm{r}$ & 0 & S.O & 50 & - & - & - \\
\hline Atriplex prostrata $(\mathrm{S})$ & 9 & $\mathrm{f}$ & 82 & S.O & 15 & 0.74 & 0.14 & 1 \\
\hline Bellis perennis (D) & 6 & $\mathrm{r}$ & 0 & J.Jl & 5 & 0.11 & 0.18 & 0.25 \\
\hline Bromus hordeaceus (D) & 2 & $\mathrm{f}$ & 1 & J.Jl & 15 & 2.85 & 0.24 & 0.17 \\
\hline Bupleurum tenuissimum (S) & 4 & $\mathrm{r}$ & 0 & - & - & 0.6 & 0.09 & - \\
\hline Calamagrostis epigejos (D) & 6 & $\mathrm{r}$ & 9 & A.S.O & 50 & 0.1 & 0.15 & 0.5 \\
\hline Carex arenaria (D) & 2 & o & 0 & A.S.O & 10 & 0.6 & 0.11 & - \\
\hline Carex distans $(\mathrm{S})$ & - & o & 216 & J1.A.S.O & 15 & 1.32 & 0.05 & - \\
\hline Carex flacca $(\mathrm{S})$ & - & o & 58 & Jl.A.S & 15 & 0.66 & 0.03 & 0.32 \\
\hline Carex oederi $(\mathrm{S})$ & - & $\mathrm{r}$ & 0 & A & 3 & - & - & - \\
\hline Carex trinervis $(\mathrm{S})$ & 2 & $\mathrm{r}$ & 0 & A & 10 & - & 0.14 & - \\
\hline Centaurium littorale $(\mathrm{S})$ & 3 & $\mathrm{r}$ & 0 & - & 10 & - & - & - \\
\hline Centaurium pulchellum (S) & 4 & $\mathrm{r}$ & 58 & S.O & 5 & 0.01 & 0.03 & 1 \\
\hline Cerastium fontanum (D) & 5 & $\mathrm{f}$ & 597 & J.Jl.A.S.O & 10 & 0.12 & - & 0.56 \\
\hline Chenopodium rubrum (S) & 9 & $\mathrm{r}$ & 1 & $\mathrm{O}$ & 15 & 0.07 & 0.16 & 1 \\
\hline Cirsium arvense (D) & 7 & $\mathrm{o}$ & 0 & A.S.O & 50 & 1.24 & 0.18 & - \\
\hline
\end{tabular}


continued

\begin{tabular}{|c|c|c|c|c|c|c|c|c|}
\hline \multirow[t]{2}{*}{ Species } & \multirow{2}{*}{$\begin{array}{l}\text { Ellenberg } \\
\text { Nitrogen } \\
\text { numbers }\end{array}$} & \multirow{2}{*}{$\begin{array}{l}\text { Occur. } \\
\text { in veg. }\end{array}$} & \multirow{2}{*}{$\begin{array}{l}\text { Seeds in } \\
\text { dung (80 1) }\end{array}$} & \multirow{2}{*}{$\begin{array}{l}\text { Months with } \\
\text { seeds present } \\
\text { in vegetation }\end{array}$} & \multicolumn{4}{|l|}{ Seed traits } \\
\hline & & & & & $\begin{array}{l}\text { Seed release } \\
\text { height }(\mathrm{cm})\end{array}$ & $\begin{array}{l}\text { Seed } \\
\text { mass } \\
(\mathrm{mg})\end{array}$ & $\begin{array}{l}\text { Seed } \\
\text { dim. } \\
\left(V_{\mathrm{s}}\right)\end{array}$ & $\begin{array}{l}\text { Seed } \\
\text { longevity } \\
\text { index }\end{array}$ \\
\hline Cirsium vulgare (D) & 8 & $\mathrm{r}$ & 0 & A & 50 & 2.37 & 0.16 & 0.17 \\
\hline Cochlearia anglica $(\mathrm{S})$ & 7 & $\mathrm{r}$ & 0 & A & 5 & - & 0.11 & - \\
\hline Cochlearia danica $(\mathrm{S})$ & 5 & $\mathrm{r}$ & 1 & J.Jl & 2 & - & 0.06 & - \\
\hline Corynephorus canescens (D) & 2 & $\mathrm{r}$ & 1 & - & - & 9.74 & 0.16 & 1 \\
\hline Cynosurus cristatus (D) & 4 & $\mathrm{r}$ & 0 & A & 40 & 0.6 & 0.14 & 0 \\
\hline Danthonia decumbens (D) & 2 & o & 0 & A & 5 & 0.84 & 0.18 & 0.27 \\
\hline Deschampsia cespitosa (D) & 3 & - & 2 & - & 20 & 0.27 & 0.16 & 0.28 \\
\hline Eleocharis uniglumis (D) & 5 & o & 16 & Jl.A & 15 & - & 0.06 & - \\
\hline Elymus athericus $(\mathrm{S})$ & 5 & $\mathrm{f}$ & 10 & J1.A.S.O & 50 & - & - & - \\
\hline Elymus repens $(\mathrm{D})$ & 7 & o & 0 & A & 50 & - & - & - \\
\hline Festuca arundinacea (S) & 4 & o & 1 & A.S.O & 50 & 1.26 & 0.17 & 0.29 \\
\hline Festuca ovina (D) & 2 & o & 8 & A.S.O & 10 & 0.32 & 0.17 & 0.04 \\
\hline Festuca rubra (S) & 6 & $\mathrm{a}$ & 379 & Jl.A.S.O & 20 & 0.79 & 0.22 & 0.12 \\
\hline Galium verum (D) & - & o & 2 & A.S.O & 15 & 0.44 & 0.02 & 0.04 \\
\hline Glaux maritima $(\mathrm{S})$ & 5 & $\mathrm{f}$ & 175 & A.S.O & 3 & - & - & 0 \\
\hline Holcus lanatus (D) & 4 & $\mathrm{f}$ & 7 & Jl.S.O & 20 & 0.31 & 0.15 & 0.44 \\
\hline Hypochaeris radicata (D) & 3 & o & 0 & A & 20 & - & - & 0.39 \\
\hline Juncus anceps (S) & - & $\mathrm{r}$ & 0 & A & 20 & 0.02 & 0.13 & - \\
\hline Juncus articulatus (S) & 2 & $\mathrm{o}$ & 122 & Jl.A.S.O & 10 & 0.02 & 0.11 & 0.86 \\
\hline Juncus ambiguus (S) & 3 & o & 205 & J1.A.S.O & 5 & 0.02 & 0.03 & 0.87 \\
\hline Juncus gerardi $(\mathrm{S})$ & - & $\mathrm{a}$ & 1252 & Jl.A.S.O & 15 & - & 0.12 & 0.63 \\
\hline Juncus maritimus (S) & 6 & $\mathrm{f}$ & 271 & Jl.A.S.O & 50 & - & - & 1 \\
\hline Leontodon autumnalis (S) & 5 & o & 1 & A.S.O & 15 & 0.71 & 0.27 & 0.12 \\
\hline Leontodon saxatilis (D) & 5 & o & 0 & $\mathrm{~A}$ & 15 & - & - & 0.5 \\
\hline Limonium vulgare $(\mathrm{S})$ & 5 & $\mathrm{f}$ & 0 & S.O & 15 & - & 0.20 & 0 \\
\hline Linaria vulgaris (D) & 5 & $\mathrm{r}$ & 0 & A & - & 0.15 & 0.20 & 0.38 \\
\hline Lolium perenne $(\mathrm{S})$ & 7 & $\mathrm{f}$ & 152 & J1.A.S.O & 15 & 1.79 & 0.19 & 0.2 \\
\hline Lotus corniculatus (D) & 3 & $\mathrm{f}$ & 24 & Jl.A.S.O & 10 & 1.25 & 0.02 & 0.14 \\
\hline Luzula campestris (D) & 2 & $\mathrm{r}$ & 5 & J.J1 & 10 & 0.76 & 0.08 & 0.18 \\
\hline Lychnis flos-cuculi (S) & - & $\mathrm{r}$ & 10 & Jl.A.S & 30 & 0.18 & 0.03 & 0.53 \\
\hline Matricaria maritima (D) & - & $\mathrm{r}$ & 0 & $\mathrm{O}$ & - & - & - & - \\
\hline Odontites vernus $(\mathrm{S})$ & 5 & $\mathrm{r}$ & 0 & A.S.O & 10 & 0.21 & 0.11 & 1 \\
\hline Ononis spinosa $(\mathrm{D})$ & 3 & o & 1 & A.S & 20 & 5.34 & 0.03 & 0 \\
\hline Parapholis strigosa (S) & 4 & $\mathrm{r}$ & 0 & A & - & - & 0.20 & - \\
\hline Phragmites australis (S) & 7 & o & 0 & S.O & - & 0.14 & - & 0 \\
\hline Plantago coronopus (D) & 4 & $\mathrm{f}$ & 903 & Jl.A.S.O & 10 & - & 0.12 & 0.33 \\
\hline Plantago lanceolata (D) & - & $\mathrm{f}$ & 157 & Jl.A.S.O & 15 & 1.81 & 0.14 & 0.38 \\
\hline Plantago major (D) & 6 & o & 129 & A.S.O & 10 & 0.26 & 0.14 & 0.78 \\
\hline Plantago maritima $(\mathrm{S})$ & 5 & $\mathrm{f}$ & 201 & S.O & 10 & 0.73 & - & 0.11 \\
\hline Poа аппиа $(\mathrm{S})$ & 8 & o & 1078 & J.Jl.A.S.O & 5 & 0.16 & 0.13 & 0.9 \\
\hline Poa pratensis $(\mathrm{D})$ & 6 & $\mathrm{a}$ & 1482 & J1.A.S.O & 10 & 0.26 & 0.18 & 0.3 \\
\hline
\end{tabular}


continued

\begin{tabular}{|c|c|c|c|c|c|c|c|c|}
\hline \multirow[t]{2}{*}{ Species } & \multirow{2}{*}{$\begin{array}{l}\text { Ellenberg } \\
\text { Nitrogen } \\
\text { numbers }\end{array}$} & \multirow{2}{*}{$\begin{array}{l}\text { Occur. } \\
\text { in veg. }\end{array}$} & \multirow{2}{*}{$\begin{array}{l}\text { Seeds in } \\
\text { dung (80 1) }\end{array}$} & \multirow{2}{*}{$\begin{array}{l}\text { Months with } \\
\text { seeds present } \\
\text { in vegetation }\end{array}$} & \multicolumn{4}{|l|}{ Seed traits } \\
\hline & & & & & $\begin{array}{l}\text { Seed release } \\
\text { height }(\mathrm{cm})\end{array}$ & $\begin{array}{l}\text { Seed } \\
\text { mass } \\
(\mathrm{mg})\end{array}$ & $\begin{array}{l}\text { Seed } \\
\operatorname{dim} . \\
\left(V_{\mathrm{s}}\right)\end{array}$ & $\begin{array}{l}\text { Seed } \\
\text { longevity } \\
\text { index }\end{array}$ \\
\hline Poa trivialis $(\mathrm{S})$ & 7 & o & 46 & Jl.A.S.O & 20 & 0.09 & 0.15 & 0.65 \\
\hline Polygonum aviculare (S) & 6 & $\mathrm{r}$ & 54 & S.O & 5 & 2.07 & - & 0.6 \\
\hline Potentilla anserina $(\mathrm{S})$ & 7 & a & 134 & Jl.A.S.O & 3 & - & 0.04 & 0.17 \\
\hline Puccinellia distans $(\mathrm{S})$ & 4 & $\mathrm{r}$ & 0 & A & 3 & - & - & 1 \\
\hline Puccinellia maritima $(\mathrm{S})$ & 5 & o & 6 & Jl.A & 3 & 0.72 & - & 0.39 \\
\hline Rorippa islandica (D) & 8 & $\mathrm{r}$ & 1 & - & - & - & - & 1 \\
\hline Rumex acetosella (D) & 2 & $\mathrm{f}$ & 37 & Jl.A.S.O & 10 & 0.36 & 0.02 & 0.71 \\
\hline Rumex crispus (D) & 5 & $\mathrm{r}$ & 0 & A.S.O & 50 & 1.44 & 0.05 & 0.69 \\
\hline Sagina maritima $(\mathrm{S})$ & 3 & $\mathrm{r}$ & 0 & $\mathrm{~J}$ & - & 0.01 & 0.06 & - \\
\hline Sagina nodosa $(\mathrm{S})$ & 5 & o & 116 & Jl.A.S.O & 5 & 0.04 & 0.01 & - \\
\hline Sagina procumbens $(\mathrm{S})$ & 6 & o & 9619 & J.J1.A.S.O & 3 & 0.02 & 0.08 & 0.88 \\
\hline Salicornia europaea $(\mathrm{S})$ & 4 & o & 7 & S.O & 10 & - & - & - \\
\hline Scirpus maritimus $(\mathrm{S})$ & 7 & o & 0 & A & 50 & - & - & - \\
\hline Scirpus rufus $(\mathrm{S})$ & 4 & $\mathrm{r}$ & 0 & A & 5 & - & - & - \\
\hline Scleranthus perennis (D) & 1 & $\mathrm{r}$ & 0 & A & 3 & 1.47 & 0.13 & - \\
\hline Sedum acre (D) & 1 & $\mathrm{r}$ & 0 & A & 3 & 0.04 & 0.11 & 0 \\
\hline Silene otites (D) & 2 & $\mathrm{r}$ & 0 & A & 20 & 0.19 & 0.07 & - \\
\hline Spartina anglica $(\mathrm{S})$ & 3 & $\mathrm{r}$ & 0 & S.O & - & - & - & 1 \\
\hline Spergularia maritima $(\mathrm{S})$ & - & o & 851 & Jl.A.S.O & 10 & - & - & - \\
\hline Spergularia salina $(\mathrm{S})$ & 5 & $\mathrm{f}$ & 7 & Jl.A.S.O & 2 & 0.07 & 0.17 & - \\
\hline Stellaria graminea (D) & 3 & $\mathrm{f}$ & 34 & Jl.A.S & 10 & 0.3 & 0.06 & 0.32 \\
\hline Stellaria media (D) & 8 & $\mathrm{r}$ & 40 & - & 5 & 0.48 & 0.07 & 0.79 \\
\hline Suaeda marítima $(\mathrm{S})$ & 7 & o & 185 & S.O & 15 & 0.33 & 0.08 & 0.09 \\
\hline Trifolium arvense (D) & 2 & o & 0 & A.S.O & 5 & 0.39 & 0.06 & 0.58 \\
\hline Trifolium campestre (D) & 3 & $\mathrm{r}$ & 0 & A & 5 & 0.35 & 0.08 & 0.33 \\
\hline Trifolium fragiferum $(\mathrm{S})$ & 7 & o & 2 & A.S & 5 & 1.34 & 0.04 & 0.63 \\
\hline Trifolium pratense (D) & - & o & 3 & A.S.O & 10 & 1.48 & 0.06 & 0.35 \\
\hline Trifolium repens $(\mathrm{S})$ & 6 & $\mathrm{f}$ & 1665 & Jl.A.S.O & 3 & 0.59 & 0.04 & 0.38 \\
\hline Triglochin maritima $(\mathrm{S})$ & 5 & o & 1 & Jl.A.S.O & 15 & 0.62 & 0.20 & 0 \\
\hline Triglochin palustris $(\mathrm{S})$ & 1 & $\mathrm{r}$ & 0 & A & 10 & 0.9 & 0.28 & - \\
\hline Tripleurospermum maritimum(D) & 8 & o & 0 & A & - & 0.31 & 0.10 & 1 \\
\hline Vicia cracca (D) & & $\mathrm{r}$ & 0 & A & 10 & 14.29 & 0.00 & 0.08 \\
\hline Vicia lathyroides (D) & 3 & $\mathrm{r}$ & 0 & J.Jl & 5 & 2.88 & 0.01 & 0.2 \\
\hline Viola curtisii (D) & 3 & $\mathrm{r}$ & 0 & A & - & - & - & - \\
\hline$x$ Calammophila baltica (D) & 4 & $\mathrm{r}$ & 0 & $\mathrm{O}$ & 50 & - & - & - \\
\hline
\end{tabular}

Key: Occurrence in vegetation: $\mathrm{a}=$ abundant; $\mathrm{f}=$ frequent; $\mathrm{o}=$ occasional; $\mathrm{r}=$ rare; $-=$ not present

(D), dune system species; (S), salt-marsh species according to Van der Meijden (1990). Nitrogen indicator value according to Ellenberg et al. (1991)

$\mathrm{J}=\mathrm{June} ; \mathrm{Jl}=\mathrm{July} ; \mathrm{A}=$ August $; \mathrm{S}=$ September, $\mathrm{O}=$ October 


\section{References}

Bakker ES, Olff H (2003) The impact of different-sized herbivores on recruitment opportunities for subordinate herbs in grassland. J Veg Sci 14:465-474

Bakker JP (1989) Nature management by grazing and cutting. Kluwer Academic Publishers, Dordrecht

Bekker RM, Bakker JP, Grandin U et al (1998) Seed size, shape and vertical distribution in the soil: indicators of seed longevity. Funct Ecol 12:834-842

Boedeltje G, Bakker JP, Ten Brinke A et al (2004) Dispersal phenology of hydrochorous plants in relation to discharge, seed release time and buoyancy of seeds: the flood pulse concept supported. J Ecol 92:786-796

Bruun HH, Poschlod P (2006) Why are small seeds dispersed through animal guts: large numbers or seed size per se? Oikos 113:402-411

Bryant JP, Chapin FS, Klein DR (1983) Carbon/nutrient balance of boreal plants in relation to vertebrate herbivory. Oikos 40:357-368

Cosyns E, Hoffmann M (2005) Horse dung germinable seed content in relation to plant species abundance, diet composition and seed characteristics. Basic Appl Ecol 6:11-24

Dai X (2000) Impact of cattle dung deposition on the distribution pattern of plant species in an alvar limestone grassland. J Veg Sci 11:715-724

Ellenberg H, Weber HE, Düll R et al (1991) Zeigerwerte von Pflanzen in Mitteleuropa. Scripta Geobot 18:9-166

Gardener CJ, Mcivor JG, Jansen A (1993) Survival of seeds of tropical grassland species subjected to bovine ingestion. J Appl Ecol 30:75-85

Klotz S, Kühn I, Durka W (2002) BIOFLOR-Eine Datenbank mit biologisch-ökologischen Merkmalen zur Flora von Deutschland. Schriftenreihe für Vegetationskunde 38:1-334

Kratochwil A, Fock S, Remy D et al (2002) Responses of flower phenology and seed production under cattle grazing impact in sandy grasslands. Phytocoenologia 32:531-552

Malo JE, Suarez F (1995a) Establishment of pasture species on cattle dung: the role of endozoochorous seeds. J Veg Sci 6:169-174

Malo JE, Suarez F (1995b) Herbivorous mammals as seed dispersers in a Mediterranean dehesa. Oecologia 104:246-255

Mitlacher K, Poschlod P, Rosén E et al (2002) Restoration of wooded meadows-a comparative analysis along a chronosequnce on Öland (Sweden). Appl Veg Sci 5:63-74
Mouissie AM, Lengkeek W, Van Diggelen R (2005a) Estimating adhesive seed dispersal distances: field experiments and correlated random walks. Funct Ecol 19:478-486

Mouissie AM, Vos P, Verhagen HMC et al (2005b) Endozoochory by free ranging, large herbivores: ecological correlates and perspectives for restoration. Basic Appl Ecol 6:547-558

Mouissie AM, Van der Veen CEJ, Veen GF et al (2005c) Ecological correlates of seed survival after ingestion by Fallow Deer. Funct Ecol 19:284-290

Pakeman RJ (2001) Plant migration rates and seed dispersal mechanisms. J Biogeogr 28:795-800

Pakeman RJ, Digneffe G, Small JL (2002) Ecological correlates of endozoochory by herbivores. Funct Ecol 16:296-304

Simao Neto MS, Jones RM, Ratcliff D (1987) Recovery of pasture seeds ingested by ruminants. I Seed of six tropical pasture species fed to cattle, sheep and goats. Austr J Exp Agri 27:239-246

SPSS Inc (2001) SPSS 11.0 for Windows. Chicago, USA

Tansley AG (1946) Introduction to plant ecology. Allen \& Unwin, London

Ter Heerdt GNJ, Verweij GL, Bekker RM et al (1996) An improved method for seed bank analysis: seedling emergence after removing the soil by sieving. Funct Ecol 10:144-151

Thompson K, Bakker JP, Bekker RM (1997) Soil seed banks of NW Europe: methodology, density and longevity. Cambridge University Press, Cambridge

Van der Meijden R (1990) Heukels' Flora van Nederland. Wolters-Noordhoff, Groningen

Vellend M, Myers JA, Gardescu S et al (2003) Dispersal of Trillium seeds by deer: implications for long-distance migration of forest herbs. Ecology 84:1067-1072

Vellend M, Knight TM, Drake JM (2006) Antagonistic effects of seed dispersal and herbivory on plant migration. Ecol Lett 9:319-326

Welch D (1985) Studies in the grazing of heather moorland in north-east Scotland. IV Seed dispersal and plant establishment in dung. J Appl Ecol 22:461-472

Wolters ME, Geertsema J, Chang ER et al (2004) Astroturf seed traps for studying hydrochory. Funct Ecol 18:141-147 